\title{
An old and agreeable companion, 1972-74
}

Doug Munro

ANUHJ Editor, 1972-74

The ANU Historical Journal (ANUHJ) entered my life well before I arrived at The Australian National University (ANU) as a Masters Qualifying student in history in 1972. In fact, the Journal was indirectly responsible for the existence of the Flinders Journal of History and Politics (1968-2015) (FJHP). It was 1968 when, as a second-year undergraduate at Flinders University, I browsed the periodical accessions in the library and stumbled across the latest issue of the ANUHJ. As I read through the elegant journal, a thought crossed my mind: if the ANU students had their own history journal, then what was stopping Flinders from having one too? It was as simple as that; the ANU history students had theirs, we should have ours.

Soon after, I discovered other student journals—the Melbourne Historical Journal $(M U J)$ and the Queensland Historical Review-but the impetus for FJHP came directly from the ANUHJ. Fellow student Jim Cotton became coeditor of FJHP and the first issue appeared the following year. ${ }^{1}$ We modelled our journal on the $A N U H J$ in having a lead article by an established academic and the bulk of remaining content by students. Actually there were two articles from senior academics in the first issue of FJHP — one from the newly appointed history professor at Flinders (George Rudé) and the other from the recently appointed politics professor at the University of Adelaide (Graeme Duncan). ${ }^{2}$

My pre-ANU link with $A N U H J$ goes one step further. In that same year at Flinders I was assigned an essay on Governor Macquarie. I was captivated by the section on 'The Age of Macquarie' in volume one of Manning

1 JS Cotton, Emeritus Professor of Politics, University of New South Wales, Canberra.

2 George Rudé, 'The "Pre-industrial” Crowd', Flinders Journal of History and Politics, no. 1 (1969), 4-18; Graeme Duncan, 'Marx and Mill and the Fate of Two Theories', Flinders Journal of History and Politics, no. 1 (1969), 30-47. 
Clark's The History of Australia, and for the first time I experienced an intensity of interest in a topic. ${ }^{3}$ Inspired, I revised and submitted the article to the ANUHJ. Months passed and towards the end of the year I received a rejection letter. I was not particularly bothered. It had been a good learning experience and the extra work in preparing it for publication had been enjoyable and instructive. In retrospect, I am glad it was not published, thereafter to haunt me as a piece of juvenilia best consigned to the closet. And what impressed me about Clark as a youngster cuts no ice with the much older version of myself. I recently re-read the section on the Macquarie era in Clark's History and could not see what I saw in it all those years ago. David Lowenthal's words immediately spring to mind: 'Old movies seen again after many years seem different not because they have altered but because we have'. ${ }^{4}$

Soon after arriving at ANU in 1972 I was elected as a coeditor of ANUHJ with KB Jackson and Phillipa Weeks. ${ }^{5}$ As well as waiting for article submissions, we actively sought contributions. The unsolicited manuscripts were a carefully honed study from John Ritchie, a history lecturer in what was then the university's School of General Studies (SGS), on 'Agatha Christie's England, 1918-39: Sickness in the Heart and Sickness in Society as Seen in the Detective Thriller', and a piece on Walter Gropius and Weimar architecture. ${ }^{6}$ The latter was a thirdyear essay, written the year before, by ANU student Martin Brady. Then there was my own joint-authored article on proposals for Pacific Islands confederation between the wars. ${ }^{7}$ I solicited the remaining four articles and the obituary.

$3 \mathrm{CMH}$ Clark, A History of Australia, Volume One: From Earliest Times to the Age of Macquarie (Melbourne: Melbourne University Press, 1962), 261-379.

4 David Lowenthal, The Past is a Foreign Country (Cambridge: Cambridge University Press, 1984), 241.

5 Last I heard, Dr Kim Jackson was working at the Australian Parliamentary Library. Phillipa Weeks became a law professor at ANU. Tragically, she died aged only 53. See Michael Coper, 'Phillipa Weeks, 1953-2006: Eulogy', accessed at law.anu.edu.au/sites/all/files/users/u4755688/phillipa_obituary.pdf.

6 Ritchie's article anticipated such studies as David Cannadine's 'Tradition: Gilbert and Sullivan as a "national institution"', in In Churchill's Shadow: Confronting the Past in Modern Britain, ed. David Cannadine (London: Allen Lane, 2000), 205-23, and David Cannadine, 'Fantasy: Ian Fleming and the Realities of Escapism', in In Churchill's Shadow, 279-311.

$7 \quad$ Many of the key references were generously provided by the retired historian of the Pacific Islands HE Maude. Much later I discovered that Maude had intended but never got around to writing such an article himself. See Maude to Helen Shiels, 27 February 1958, Papers of HC \& HE Maude, MSS 0003, Series J, Special Collections, Barr Smith Library, University of Adelaide. 
The reviews were a decidedly mixed bag. Whereas FJHP only reviewed books authored or edited by academics at Flinders University and the University of Adelaide, we tended to invite reviewers for as many of the books we received as we could, and more often than not students did the honours. In the 1972 issue, three of the books reviewed concerned Pacific Island history, a fact which reflected the interests of Kim Jackson and myself. In these instances, we had requested review copies.

There was no major crisis with the 1972 issue (number 9). I do not recall difficulties in garnering the articles, but a lack of communication did cause extra work. The articles and reviews were typed as a camera-ready copy, either in the History Department or the Students' Representative Council. Rather than providing a photocopy, we gave John Ritchie the only copy of the proofs of his article for checking, but without saying that any corrections be noted on a separate sheet of paper. His corrections, in his impeccably neat handwriting, were entered on to the camera-ready copy, which then had to be retyped.

More seriously, number 9, although nominally published in December 1972, actually appeared in September 1973. The delay was caused by my decision to finish writing my qualifying thesis unimpeded. Editing FJHP had set back my studies in 1969 and I did not want this to happen again. Kim and Phillipa were in their honours year and it was too much to expect them to take time out at the end of the year; indeed, both were awarded First Class Honours degrees. The delays occasioned murmurings of discontent at the AGM of the Historical Society and outright annoyance from John Ritchie, who was never adept at concealing his impatience. ${ }^{8}$ Number 9 did eventually put in an appearance, but not to universal acclaim. Ritchie's feedback was that the Pacific Islands were over-represented and I take his point.

Ever a glutton for punishment, I was appointed a joint editor for the next issue of $A N U H J$ along with fellow editors Kim Jackson (again) and Phil Carpenter. Because we were effectively a year behind the calendar, we decided on a double issue covering the years 1973-74. Again I assumed

8 John Ritchie went on to become the General Editor of the Australian Dictionary of Biography in 1987. His ability to attract external money in all likelihood saved the ADB from going under. See Geoffrey Bolton, 'John Ritchie: Consolidating a Tradition, 1987-2002', in The ADB's Story, ed. Melanie Nolan and Christine Fernon (Canberra: ANU E Press, 2013), 153-71: doi.org/10.22459/ ADBS.10.2013.05; Ian Hancock, 'John Ritchie, 1941-2006', History Australia 3, no. 2 (2006), 52.1-3. 
most of the responsibility despite taking up a postgraduate scholarship at Macquarie University. The arrangement was only feasible because I spent several months of 1974 in Canberra, researching in the National Library of Australia.

The double number 1973-74 was a bigger issue (90 pages as against 50) and again there were few problems along the way. The content was far less Pacific Islands-oriented and the book reviews were far more weighted in favour of Australian history. This time there were two articles by academics, both ANU-based. One was a submission on 'What was "Colonial Independence"?' by Ged Martin, which was the start of an enduring friendship. ${ }^{9}$ The other was more serendipitous. FB ('Barry') Smith suggested that we republish an important book chapter on 'The Irish in Victoria, 1851-91: A Demographic Essay' by Oliver MacDonagh, the recently appointed history professor at the then Institute of Advanced Studies at ANU, in order that it might be rescued from the confines of a somewhat obscure Irish publication and given greater visibility in Australia. ${ }^{10}$

The article had a faintly amusing sequel. When numbers 10-11 emerged, I was flogging them off in Union Court. It was fortuitous timing because the Australian Historical Association Conference was being held at ANU and academics from other universities were on campus. One of those was Patrick O'Farrell, a specialist on Irish history. We were known to each other and he graciously purchased a copy, saying in the most kindly terms how important it was to support such ventures. But one look at the table of contents provoked a dramatic transformation. He erupted with anger: 'Oliver, the old bugger, he's gone and republished that essay!' 'Yes', I stammered, startled by the outburst, 'Barry Smith suggested we should and we were very glad to have it', but Pat was not mollified. Such was my first encounter of territoriality, or at least a patrolling of the boundaries, among historians. ${ }^{11}$

9 Ged Martin is Emeritus Professor Canadian Studies at the University of Edinburgh.

10 Oliver MacDonagh was foundation professor of history at Flinders University when I was a firstyear student but had departed before FJHP was conceived. See Doug Munro, 'Oliver MacDonagh at Flinders University, 1964-1968', Australian Historical Association Bulletin 86 (1998), 45-58.

11 Both O'Farrell's and MacDonagh's work on the Irish in Australia has been re-examined. See Donald Harman Akensen, Small Differences: Irish Catholics and Irish Protestants, 1815-1922: An International Perspective (Montreal \& Kingston: McGill-Queen’s University Press, 1988), 59-66. 
Another episode concerns my decision to include a listing of all the honours (and MA Qualifying) theses held by SGS's History Department. The idea came from FJHP where, in 1969, we listed all the history theses in progress, which in turn was inspired by a similar section in the New Zealand Journal of History. So I telephoned Shirley Bradley, the departmental secretary, in order to gain access to the room in which the theses were held. I must have caught her at a bad moment because she was not especially cordial to my request, but I stuck to my guns and she eventually relented. In fairness, she did relax and was her usual friendly self by the time I had finished. It's funny how certain things stick in your mind.

On the other hand, there was a case of lost opportunity. Laurie Fitzhardinge's obituary of Douglas Pike, the General Editor of the Australian Dictionary of Biography, was published in June $1974 .{ }^{12}$ I should have sought Laurie's permission to reprint there and then, but the decision to include the obituary was an afterthought. It suddenly occurred to me that the obituary would fit into the inside back cover. I phoned Laurie a couple of times but could not get hold of him. The Journal was almost ready for the printer and without Laurie's explicit approbation I felt unable to include his obituary of Pike. Such are the consequences of delay.

There was also the review of Frank Crowley's two-volume Modern Australia in Documents. John Ritchie declined to review them, explaining that his field was the nineteenth century whereas the Crowley volumes covered the years 1900-70. He suggested Humphrey McQueen, whose field was twentieth-century Australia. I was aware that Humphrey dished out bracing reviews; he believed that Australia historians' politeness toward each other's work - 'the gentility principle', as he called it—was inimical to ' $[\mathrm{t}$ ] he idea of the university as a clash of ideas', and he was going to put things to rights. ${ }^{13} \mathrm{Had}$ I also realised that Crowley was a bette noire of Humphrey's, I would probably have looked elsewhere. Let's just say that Humphrey did not disappoint.

The combined numbers $10-11$ were definitely superior to their predecessor. The most pleasing contribution would have to be Dennis Shoesmith's review article of Geoffrey Serle's book on the creative spirit in Australia (From Deserts the Prophets Come). It was the only refereed contribution and Dennis

12 LF Fitzhardinge, 'Professor Pike Obituary', ANU Reporter, 28 June 1974, 2, accessed at oa.anu. edu.au/uploads/obituaries/818/pike_douglas_obit_1974.pdf.

13 Frank Bongiorno, 'Two Radical Legends: Russel Ward, Humphrey McQueen and the New Left Challenge in Australian Historiography', Journal of Australian Colonial History 10, no. 2 (2008), 214. 
felt that the referee had been too interventionist. In retrospect, I should have let Dennis decide which of the recommendations he was prepared to accept rather than foisting them upon him. To his delight, Dennis received a sincere letter of appreciation from the author, stating that his review was by far the best. ${ }^{14} \mathrm{I}$ am left wondering whether the review article would have been better still had I allowed the original version to stand.

For all that, a mistake towards the end of the production line took the shine off our efforts. The individual pages often had to be cut and pasted to get them camera-ready, and in doing so I made some blunders. Specifically, some lines are repeated on page 31 of the MacDonagh article (and the spacing is awry). Oliver was disappointed, especially as he had offered to proofread his article, but he did not berate me. Rather more serious were a few lines being omitted from a footnote in one of the two review articles. Worst of all—and irony of ironies—was 75 words being omitted from my own book review. This episode demonstrates how much more difficult it was to produce a journal before the advent of word processing, and what this implies for editing and printing. Such a cock-up would not have happened with today's technology.

I can hardly begin to describe how pissed off I was with myself upon discovering the mishaps one evening, after the Journal had been printed and bound. In a very dark and despondent frame of mind, I trudged to the ANU Staff Club to drown my sorrows. Once there I poured out my tale of woe to Kevin Fewster, whom I had known two years earlier at Bruce Hall, and who was one of the reviewers for numbers $10-11 .{ }^{15} \mathrm{In}$ the event an erratum slip was pasted into each copy, a business that was as tedious as it was disheartening.

Looking back, I cannot regret my involvement in student journals, which was the precursor to my connection down the years with several other academic journals. ${ }^{16}$ The work I did with the FJHP and the ANUHJ was interesting and rewarding. There was a sense of accomplishment. You felt you were making a contribution, perhaps even a difference.

14 High praise indeed considering the other reviews included Russel Ward, C Hartley Grattan and Bernard Smith in 'High Culture in Australia' [review forum], Historical Studies 16, no. 63 (1973), 286-91: doi.org/10.1080/10314617408682890. Dennis Shoesmith is now University Professorial Fellow at Charles Darwin University.

15 Dr Kevin Fewster is currently Director of the National Maritime Museum, United Kingdom.

16 Journal of Pacific Studies (guest editor of two special issues); History Now (regular interviewer); Journal of Pacific History (review editor); Journal of Historical Biography (editorial board and co-editor of a special issue); Journal of Labor and Society (associate editor) and Using Lives: Essays in Australian biography and history (editorial board). 
While unwavering in my support for student history journals, I have come to wonder whether these should cater primarily as outlets for undergraduate endeavours. Historians mature later than scientists and mathematicians, thus running the risk of premature publication. Precociousness of the order displayed by Geoffrey Blainey in publishing his first academic article in a mainstream journal at age 20 , and in the process critiquing the work of a full professor, is highly exceptional. ${ }^{17}$ It is no wonder, then, that FJHP and the Melbourne Historical Journal transformed into outlets for postgraduate research; and that later student history journals-namely Limina (University of Western Australia) and ERAS Journal (Monash University)-likewise cater for postgraduates.

The late 1960s and 1970s were a good time to be a university student. As I have written elsewhere, FJHP'was a reflection of a young and vibrant Flinders [University] where worthwhile things were done sooner or later'. ${ }^{18}$ That same vibrancy was evident during my student days at ANU. Speaking strictly for myself, editing student history journals was part of that vibrancy. It was an endeavour worth doing and given the chance I would do it all over again, although I am sure I could do it better the second time around.

Doug Munro is an Adjunct Professor of History at the University of Queensland. He is now in retirement and occupies what passes for an exciting life in writing biographical studies of historians. His recent publications include Clio's Lives: Biographies and Autobiographies of Historians (coedited with John G Reid) and Bearing Witness: Essays in Honour of Brij V. Lal (coedited with Jack Corbett). Both were published in 2017 by ANU Press. His article on 'The House that Hugh Built: The Adelaide History Department during the Stretton Era, 19541966', History of Education 46, no. 5 (2017), 631-52, won the 2018 Wakefield Companion Prize for the best essay on an aspect of South Australian history.

17 Geoffrey Blainey, 'The Role of Economic Interests in Australian Federation: A reply to Professor Parker', Historical Studies, Australia and New Zealand 4, no. 15 (1950), 224-37: doi.org/10.1080/ 10314615008594897.

18 Doug Munro, 'Those Glorious Days: Flinders in the Late-Sixties', Flinders Journal of History and Politics 13 (1988-89), 3. 
This text is taken from ANU Historical Journal II: Number 1, published 2019 by ANU Press, The Australian National University, Canberra, Australia.

doi.org/10.22459/ANUHJII.2019.06 